\title{
Cytogenotoxic and mutagenic profiling of cashew nut shell liquids and cardanol
}

\author{
Aracelli de Sousa Leite ${ }^{1}$, Muhammad Torequl Islam² ${ }^{2^{*}}$, Márcia Fernanda Correia Jardim Paz ${ }^{1}$, \\ Antônio Luiz Gomes Júnior ${ }^{1}$, George Laylson da Silva Oliveira' ${ }^{1}$, Antônia Maria das Graças Lopes Cito ${ }^{3}$, \\ Ana Amélia de Carvalho Melo-Cavalcante ${ }^{1,4}$ and José Arimatéia Dantas Lopes ${ }^{1,3}$
}

\begin{abstract}
Background: Cashew and its compounds have many important biological effects. This study is aimed at evaluating genotoxic and mutagenic effects of natural cashew nut shell liquid (nCNSL) and industrial cashew nut shell liquid (iCNSL) and a major component of iCNSL called Cardanol.

Methods: Test samples were undergone for comet assay and micronucleus tests in Swiss albino mice. Animals were orally treated with $17.37,34.75$ and $69.5 \mathrm{mg} / \mathrm{kg}$ of the test substances taking distilled water $(10 \mathrm{~mL} / \mathrm{kg} ; \mathrm{DW})$ and cyclophosphamide $(50 \mathrm{mg} / \mathrm{kg}$ ) as negative (NC) and positive (PC) controls, respectively.

Results: The results suggest that nCNSL at 34.7 and $69.5 \mathrm{mg} / \mathrm{kg}$ and Cardanol at all tested doses induced significant genotoxic effects to the female mouse bone marrow cells, while iCNSL did not. Both nCNSL and iCNSL as well as Cardanol did not show mutagenic and cytotoxic effects. All the test samples also showed DNA repair capacity at low dose.
\end{abstract}

Conclusion: Cashew nut shell liquids and Cardanol showed genotoxic effects at high dose, but DNA repair, nonmutagenic and non-cytotoxic effects at low dose.

Keywords: Anacardium occidentale, Cardanol, Genotoxicity, Mutagenicity, Mus musculus

\section{Introduction}

The family, Anacardiaceae consisting of more than 70 genera with 600 species is distributed in tropical and sub-tropical regions throughout the world [12]. The genus, Anacardium is composed of 11 species in which Anacardium occidentale stands out most [41]. A. occidentale is a tree native to the Central America, the Caribbean Islands, and northern South America and also cultivated in several countries such as Vietnam, India, and Ivory Coast. Various parts of this plant have been used as tropical medicine in diabetic [31], gastrointestinal complications [4], and bacterial infections [28].

The real fruit of $A$. occidentale grows on the edge of pseudo one called 'cashew' and chestnut releases a liquid known as cashew nut shell liquids (CNSLs) [33]. It is

\footnotetext{
* Correspondence: dmt.islam@bsmrstu.edu.bd

²Department of Pharmacy, Life Science Faculty, Bangabandhu Sheikh

Mujibur Rahman Science and Technology University, Gopalganj, Dhaka 8100,

Bangladesh

Full list of author information is available at the end of the article
}

considered as a natural source of meta-alkyl phenols which is a mixture with saturated and unsaturated side chains [20]. CNSLs can be obtained by several extraction processes such as cold extraction [21], vacuum pyrolysis extraction $\left(500{ }^{\circ} \mathrm{C}\right.$ and at $720 \mathrm{mmHg}$ ), and supercritical carbon dioxide-induced extraction [36]. CNSLs, obtained by the solvent extraction called natural CNSLs (nCNSL), while industrially or technically processed at high temperatures is the iCNSL [21].

The nCNSL is mainly composed of Anacardic acid (70\%), Cardanol (5\%) and Cardol (18\%) [5], whereas iCNSL by Cardanol (60-65\%), Cardol (15-20\%), polymer material $(10 \%)$ and a trace amount of 2-methyl Cardol. This difference in chemical composition may be due to the fact that at high temperature Anacardic acid can be decarboxylated to Cardanol [21].

The cashew nuts contain phenolic compounds with antioxidant activity $[19,44]$ and can be used to treat the incidence of chronic and degenerative diseases, including cancer, cardiovascular and neurodegenerative diseases 
[39]. CNSLs have been also reported for many other diverse pharmacological effects such as insecticidal [13], larvicidal and antiacetylcholinesterase [7, 34], anti-inflammatory [8], antioxidant [3], anxiolytic [14], antibacterial [27], and so on. In a recent study, it has been reported that the CNSLs may impart genotoxic effects in prokaryotic and eukaryotic systems [24]. Thus, this study is aimed to conduct the genotoxic and mutagenic effects of nCNSL, iCNSL and the major component of iCNSL, Cardanol by adapting the micronucleus and comet assay tests in mouse bone marrow.

\section{Materials and methods}

\section{Sample colection and extraction}

The cashew nut shells were collected from Teresina, Brazil and were stored in a cooler in liquid nitrogen for 5 min. The dried materials, then crushed, subjected to extraction with $\mathrm{n}$-hexane in a Sohxlet apparatus for $16 \mathrm{~h}$. The solvent was then evaporated by using a rotary evaporator, yielded iCNSL [24]. The tCNSL was kindly provided by the Europa Chestnut Industry Ltda group (Altos, Piaui, Brazil). Both iCNSL and tCNSL were stored at room temperature until the test commenced.

\section{CNSL methylation reaction and GC-MS analysis}

The nCNSL and iCNSL were analyzed by gas chromatography coupled to mass spectrometry (GC-MS) in the form of methyl esters. Briefly, $5 \mathrm{mg}$ of CNSL was dissolved in $0.5 \mathrm{~mL}$ of diethyl ether and transferred to a 5.0 $\mathrm{mL}$ flask. A solution of diazomethane in ether $(2 \mathrm{~mL})$ was then added dropwise at low temperature in an ice bath until outgassing was no longer observed. The flask was sealed with a ground glass stopper and magnetically stirred continuously at room temperature. After $3 \mathrm{~h}$, the reaction was monitored by thin layer chromatography (TLC), then followed by ether evaporation, residue solubilization in ethyl acetate and analysis by GC-MS system (Shimadzu, GC-17A/MS-QP5050A). The column chromatography DB-5HT (J \& W Scientific) was $30 \mathrm{~m}$ long and $0.25 \mathrm{~mm}$ in diameter, had a film thickness of $0.10 \mu \mathrm{m}$, and used helium as a carrier gas $(1.0 \mathrm{~mL} / \mathrm{min})$. The following parameters were used: interface $=270{ }^{\circ} \mathrm{C}$, injector $=250^{\circ} \mathrm{C}$, initial temperature $=60^{\circ} \mathrm{C}(2 \mathrm{~min}), 4.0$ $\mathrm{mL} / \mathrm{min}$ to $180^{\circ} \mathrm{C}(4 \mathrm{~min})$, and $10 \mathrm{~mL} / \mathrm{min}$ to $260^{\circ} \mathrm{C}(10$ $\mathrm{min})$. Identification was achieved by comparing mass spectra (43 to $4500 \mathrm{Da}$, electron impact ionization, 70 eV) MS $[16,25]$.

\section{Experimental animals}

Mice (Mus musculus) of either sex with 20-30 g body weight, obtained from the Central Animal Facility of the Federal University of Piauí - UFPI, Teresina, PI, Brazil were used in this study. The animals were housed in polypropylene cages keeping without food restrictions (Labina-Purina) and fluid intake throughout the experiment ensured at $22 \pm 3{ }^{\circ} \mathrm{C}$ at $50-60 \%$ humidity with a $12 \mathrm{~h}$ light/ dark cycle. Animal experiments were carried out in accordance with the NIH guidelines.

\section{Treatments}

The animals were divided into eleven groups: (1) negative control (NC) - no treatment; (2-4) nCNSL (17.3, 34.7 and $65.9 \mathrm{mg} / \mathrm{kg}) ;(5-7)$ iCNSL $(17.3,34.7$ and 65.9 $\mathrm{mg} / \mathrm{kg}) ;(8-10)$ Cardanol (17.3, 34.7 and $65.9 \mathrm{mg} / \mathrm{kg}$ ) and (11) Positive control - cyclophosphamide $(50 \mathrm{mg} / \mathrm{kg}$; PC). The solutions nCNSL, iCNSL and Cardanol were diluted with $0.05 \%$ Tween 80 (solvent). The test solutions were administered by oral gavage (p.o.).

\section{Comet assay}

The comet assay was performed with slight modification of the method described by Tice et al. [43]. After an interval of $24 \mathrm{~h}$ of treatment; the animals were sacrificed by cervical dislocation, and carried out the collection of bone marrow. Cells were extracted from both femurs in $2 \mathrm{~mL}$ of fetal bovine serum. The slides were previously coated with a layer of agarose with normal melting point (NMPA; 0.75\%) in phosphate buffer saline (PBS; pH 7.4) and stored in a dark room, wet at $4{ }^{\circ} \mathrm{C}$ until test commenced $(24 \mathrm{~h})$. After incubation, $0.01 \mathrm{~mL}$ of cell suspension was added to $90 \mathrm{~mL}$ of low melting point agarose (LMPA; $1.5 \%$ ) at $35^{\circ} \mathrm{C}$ and the mixture was added to NMPA pre-coated slides and covered with cover slips. After solidification of the cell suspension, slides were then immersed in lysing solution (10\% DMSO, 1\% Triton X-100 mM Tris, $2.5 \mathrm{M} \mathrm{NaCl}, 100 \mathrm{mM}$ EDTA, pH 10.0 to 10.5 ) for $72 \mathrm{~h}$ at $4{ }^{\circ} \mathrm{C}$. After the time elapsed, slides were then rinsed with DW, placed horizontally in an electrophoretic tank and covered with fresh electrophoresis buffer $(0.0075 \mathrm{M}$ EDTA $1 \mathrm{mM}, \mathrm{pH} 13)$ for 20 $\mathrm{min}$. Electrophoresis was performed for $15 \mathrm{~min}$ at 300 $\mathrm{mA}$ and $25 \mathrm{~V}$, then followed by neutralization $(400 \mathrm{mM}$ Tris; $\mathrm{pH} 7.5)$, fixation (15\% v/v trichloroacetic acid, $5 \%$ $\mathrm{v} / \mathrm{v}$ of zinc sulfate, $5 \%$ glycerol), washing with $\mathrm{DW}$ and an over-night drying at $18{ }^{\circ} \mathrm{C}$. The gels were then rehydrated for $5 \mathrm{~min}$ in DW and stained for $15 \mathrm{~min}\left(37^{\circ} \mathrm{C}\right)$ $\{1$ part of solution B $(0.2 \% \mathrm{v} / \mathrm{v}$ ammonium nitrate, $0.2 \%$ silver nitrate v/ v, 0.5\% v/v tungstosalisilic acid, $0.15 \% \mathrm{v} /$ $\mathrm{v}$ formaldehyde, $5 \% \mathrm{v} / \mathrm{v}$ sodium carbonate) and 3 part solution A (sodium carbonate to $5 \%$ )\}. Subsequent addition of stop solution (1\% acetic acid gels) and dry at room temperature was performed. Finally, a total of 100 cells was analyzed randomly per treatment at 100X magnification by using an optical microscope. Two parameters were considered, such as index of damage (ID; 0-400) and frequency of damage (FD; 0-100\%). For the calculation of identity, the cells were visually classified into five categories according to the size of comet tails $(0=$ no tail, $4=$ maximum length of the tail), which resulted in a DNA damage score for each 
sample and hence for each group. Degree of freedom (DF) in percentage was calculated for each sample based on the number of cells with tails compared to damaged cells with zero (0) damage. All slides were coded for blind analysis.

\section{Micronucleus assay}

The micronucleus (MI) assay was performed by using bone marrow cells of mice in line with the recommendations of the Environmental Protection Agency program, Gene-Tox [30]. After a $24 \mathrm{~h}$ the slides were fixed with methanol/acetic acid (3:1) and stained with a mixture of methylene blue (Giemsa staining, May-Grunwald) and 0.2 M phosphate buffer ( $\mathrm{pH} 5.8$ ) with the ratio of 6:3:1 respectively. Photomicrographic analysis was performed at $40 \mathrm{X}$ by using an optical microscope. The study only examined the cells that showed intact cytoplasm as for the relevant nuclear changes cytotoxicity was considered the presence of binucleated cells (BN) [15]. To avoid fake results and as an indication of cytotoxicity for this, we calculated the ratio of normochromatic erythrocytes and polychromatic erythrocytes (EPC/ENC) in 1000 cells. The incidence of $\mathrm{MN}$ and $\mathrm{BN}$ was observed in 2000 cells (EPC 1000/slide/animal).

\section{Statistical analysis}

For this purpose Graph Pad Prism 6.0 (Graph pad Inc., San Diego, CA) was used. Two-way analysis of variance (ANOVA) followed by Tukey's test was applied for multiple comparisons between the study groups. Spearman correlation was used to compare the biomarkers of genotoxicity and mutagenicity. The calculated values are expressed as mean \pm standard deviation (SD) by considering $p<0.05, p<0.001$ and $p<0.0001$.

\section{Results}

\section{Genotoxic effect (comet assay)}

Table 1 shows the genotoxic activities of nCNSL, iCNSL and Cardanol in mouse bone marrow cells. The ID and FD have shown for the PC group are suggesting its genotoxic effect when compared with the NC group. The nCNSL produced a significant genotoxic effect with two highest doses (34.7 and $69.5 \mathrm{mg} / \mathrm{kg}$; p.o.) in female mice, while iCNSL exhibited insignificant genotoxicity by all tested doses. On the other hand, Cardanol exhibited significant genotoxic effect to the female mice at all tested doses.

\section{Cytotoxic and mutagenic effects (MN test)}

Both nCNSL and iCNSL, and Cardanol exhibited no cytotoxicity in mouse bone marrow cells when compared to the NC (DW) group. Moreover, there were no significant binucleated cells (BN) as compared to the NC marked group (Table 2). But the PC produced an
Table 1 Overview of damage and damage rate (mean \pm SD) in bone marrow cells of mice after $24 \mathrm{~h}$ of oral (p.o.) administration of nCNSL, iCNSL and Cardanol

\begin{tabular}{|c|c|c|c|c|}
\hline \multirow{2}{*}{\multicolumn{2}{|c|}{ Groups }} & \multirow{2}{*}{$\begin{array}{l}\text { Sex } \\
M\end{array}$} & \multirow{2}{*}{$\begin{array}{l}\text { Damage Index } \\
15.0 \pm 3.6\end{array}$} & \multirow{2}{*}{$\begin{array}{l}\text { Frequency of Damage } \\
14.8 \pm 3.4\end{array}$} \\
\hline & & & & \\
\hline & & $F$ & $10.2 \pm 1.3$ & $10.2 \pm 1.3$ \\
\hline \multirow{2}{*}{\multicolumn{2}{|c|}{$P C^{b}(50$ mg/kg) }} & M & $120.2 \pm 10.8^{\mathrm{a}}$ & $98.6 \pm 1.3^{\mathrm{a}}$ \\
\hline & & $F$ & $98.8 \pm 1.3^{a}$ & $98.8 \pm 1.3^{\mathrm{a}}$ \\
\hline \multirow[t]{6}{*}{ nCNSL (mg /kg) } & 17.3 & M & $64.2 \pm 36.5$ & $60.0 \pm 32.5$ \\
\hline & & $F$ & $59.8 \pm 29.8$ & $52.8 \pm 26.6$ \\
\hline & 34.7 & M & $54.2 \pm 21.2$ & $47.2 \pm 37.0$ \\
\hline & & $\mathrm{F}$ & $76.6 \pm 16.1^{c}$ & $64.2 \pm 11.0^{c}$ \\
\hline & 69.5 & M & $48.0 \pm 30.4$ & $39.8 \pm 19.2$ \\
\hline & & $F$ & $86.6 \pm 14.8^{b}$ & $67.0 \pm 4.4^{a}$ \\
\hline \multirow[t]{6}{*}{ iCNSL (mg /kg) } & 17.3 & M & $13.2 \pm 5.2$ & $12.0 \pm 5.4$ \\
\hline & & $F$ & $16.2 \pm 12.1$ & $16.2 \pm 12.1$ \\
\hline & 34.7 & M & $20.8 \pm 13.0$ & $13.6 \pm 3.4$ \\
\hline & & $F$ & $17.2 \pm 6.3$ & $16.6 \pm 6.6$ \\
\hline & 69.5 & M & $21.4 \pm 11.6$ & $21.2 \pm 11.4$ \\
\hline & & $F$ & $19.0 \pm 18.1$ & $19.0 \pm 18.1$ \\
\hline \multirow[t]{6}{*}{ Cardanol (mg $/ \mathrm{kg}$ ) } & 17.3 & M & $47.0 \pm 21.5$ & $40.4 \pm 8.3$ \\
\hline & & $F$ & $62.2 \pm 12.6^{b}$ & $51.8 \pm 5.5^{b}$ \\
\hline & 34.7 & M & $43.4 \pm 6.1$ & $37.6 \pm 5.3^{b}$ \\
\hline & & $\mathrm{F}$ & $66.4 \pm 7.4^{b}$ & $55.4 \pm 4.2^{a}$ \\
\hline & 69.5 & M & $47.0 \pm 21.7$ & $44.4 \pm 9.3$ \\
\hline & & $\mathrm{F}$ & $61.2 \pm 12.13^{b}$ & $51.8 \pm 5.5^{b}$ \\
\hline
\end{tabular}

NC: negative control (DW); PC: positive control (cyclophosphamide); nCNSL/ iCNSL/Cardinol (17.3, 347 and $69.5 \mathrm{mg} / \mathrm{kg}$ ); index of damage (ID): 0 (no damage, $0 \times 100$ cells) 400 (maximum damage, $4 \times 100$ cells); frequency of damage (FD): based on the number of cells with tail-tail cell lines; significance compared to the negative control ${ }^{\mathrm{a}} p<0.0001 ;{ }^{\mathrm{b}} p<0.01 ;{ }^{\mathrm{c}} p<0.05$; two-way ANOVA (with non-parametric test) followed by Tukey's test $(n=10$ animals; M5:F5)

increased formation of MNs $(p<0.001)$ when compared to the NC group.

\section{Discussion}

Medicinal plants may have mutagenic, co-carcinogenic and/or carcinogenic effects, although they have varieties of potential therapeutic indications [1]. The substances having antioxidant capacities can prevent/treat diseases like cancer, arteriosclerosis and diabetes [24], which are mainly caused by mutations or errors in the metabolic process and are considered as mutagenic substances with the power to destroy the integrity of DNA and increase the incidence of cancer. Thus, genotoxicity biomarkers by using the comet assay and the MN test can be used to detect the damage to the genetic materials [11].

According to Oliveira et al. [34] the Anacardic acid is the main constituent of nCNSL, which undergoes 
Table 2 Determination of binucleated cells with micronuclei (mean \pm SD) in bone marrow cells of mice after $24 \mathrm{~h}$ of oral administration of nCNSL, iCNSL and Cardanol

\begin{tabular}{|c|c|c|c|c|c|}
\hline \multirow[t]{2}{*}{ Groups } & & \multirow[t]{2}{*}{ Sex } & \multirow[t]{2}{*}{ Micronucleus } & \multicolumn{2}{|l|}{ Relation } \\
\hline & & & & EPC/NPC & Binucleated \\
\hline \multirow{2}{*}{\multicolumn{2}{|c|}{$N C^{a}(10 \mathrm{ml} / \mathrm{kg})$}} & M & $1.0 \pm 0.5$ & $1.7 \pm 0.2$ & $13.1 \pm 3.2$ \\
\hline & & $\mathrm{F}$ & $1.0 \pm 0.5$ & $1.7 \pm 0.2$ & $13.1 \pm 3.2$ \\
\hline \multirow{2}{*}{\multicolumn{2}{|c|}{$P C^{b}(50 \mathrm{mg} / \mathrm{kg})$}} & M & $13.8 \pm 1.5^{\mathrm{a}}$ & $0.5 \pm 0.2^{a}$ & $145.8 \pm 42.7^{\mathrm{a}}$ \\
\hline & & $\mathrm{F}$ & $15.0 \pm 2.5^{\mathrm{a}}$ & $0.5 \pm 0.2^{\mathrm{a}}$ & $145.8 \pm 42.7^{\mathrm{a}}$ \\
\hline \multirow[t]{6}{*}{ nCNSL (mg /kg) } & 17.3 & M & $3.0 \pm 1.0$ & $1.7 \pm 0.1$ & $2.3 \pm 0.3$ \\
\hline & & $\mathrm{F}$ & $1.0 \pm 0.4$ & $1.4 \pm 0.3$ & $2.8 \pm 0.2$ \\
\hline & 34.7 & M & $2.0 \pm 0.5$ & $1.5 \pm 0.3$ & $2.6 \pm 0.4$ \\
\hline & & $\mathrm{F}$ & $1.4 \pm 0.2$ & $1.3 \pm 0.0$ & $2.6 \pm 0.4$ \\
\hline & 69.5 & M & $2.6 \pm 0.4$ & $1.6 \pm 0.3$ & $2.1 \pm 0.3$ \\
\hline & & $\mathrm{F}$ & $2.0 \pm 0.3$ & $1.2 \pm 0.2$ & $3.0 \pm 0.3$ \\
\hline \multirow[t]{6}{*}{ iCNSL (mg /kg) } & 17.3 & M & $1.2 \pm 0.3$ & $1.2 \pm 0.2$ & $2.2 \pm 0.5$ \\
\hline & & $\mathrm{F}$ & $0.8 \pm 0.3$ & $1.3 \pm 0.3$ & $3.0 \pm 0.3$ \\
\hline & 34.7 & M & $1.4 \pm 0.4$ & $1.6 \pm 0.3$ & $2.0 \pm 1.4$ \\
\hline & & $\mathrm{F}$ & $1.6 \pm 0.5$ & $1.2 \pm 0.2$ & $3.6 \pm 2.3$ \\
\hline & 69.5 & M & $1.0 \pm 0.4$ & $1.5 \pm 0.5$ & $1.6 \pm 0.9$ \\
\hline & & $\mathrm{F}$ & $1.6 \pm 0.2$ & $1.7 \pm 0.6$ & $1.0 \pm 0.4$ \\
\hline \multirow[t]{6}{*}{ Cardanol (mg /kg) } & 17.3 & M & $2.0 \pm 0.0$ & $1.2 \pm 0.1$ & $2.8 \pm 0.2$ \\
\hline & & $\mathrm{F}$ & $2.2 \pm 0.2$ & $1.2 \pm 0.1$ & $3.4 \pm 0.0$ \\
\hline & 34.7 & M & $1.6 \pm 0.2$ & $1.5 \pm 0.2$ & $3.7 \pm 0.9$ \\
\hline & & $\mathrm{F}$ & $2.2 \pm 0.2$ & $1.4 \pm 0.2$ & $3.8 \pm 0.7$ \\
\hline & 69.5 & M & $1.2 \pm 0.2$ & $1.5 \pm 0.3$ & $2.7 \pm 0.2$ \\
\hline & & $\mathrm{F}$ & $2.0 \pm 0.3$ & $1.7 \pm 0.5$ & $3.4 \pm 0.0$ \\
\hline
\end{tabular}

NC: negative control (DW); PC: positive control (cyclophosphamide); nCNSL/iCNSL/Cardanol (17.3, 347 and 69.5 mg/kg); BN: binucleated, EPC/NPC: polychromatic cells/normochromatic cells; ${ }^{a} p<0.0001$ compared to the NC; two-way ANOVA (with non-parametric test) followed by Tukey's test ( $\mathrm{n}=10$ animals; M5:F5)

decarboxylation at high temperature. However, the conditions of burning chestnuts can change the composition of iCNSL. Furthermore, the climatic conditions, the origin of the chestnuts and the extraction process are other important facts that can be considered to explain the difference in the chemical composition for the presence of phenolic compounds in CNSLs [6].

The cyclophosphamide (PC) is a chemotherapeutic drug; whichever induces damage to the chromosomes underwent formation of free radicals and alkylation of DNA, leading to mutagenesis [38]. It is considered as a clastogenic effect after metabolic activation and DNA damage inducer in leukocytes and cells of the duodenum of rodents in the comet assay [37]. In our study, it is evident that PC increased DNA damage in test animals, probably due to chromosomal breaks and increased frequency of MN formation.

Going through the parameters as ID and FD, it was observed that the occurrence of DNA damage by Cardanol $(17.3 \mathrm{mg} / \mathrm{kg})$ produced statistically significant $(p<$ 0.05 and $p<0.01)$ result. The nCNSL was found to be more effective at $69.5 \mathrm{mg} / \mathrm{kg}$ while Cardanol at $34.7 \mathrm{mg} / \mathrm{kg}$ in the female mice. However, Cardanol caused damage in relation to $\mathrm{FD}$ at $69.5 \mathrm{mg} / \mathrm{kg}$ in male and female mice. There may be a link to the Anacardic acid present in larger quantities $(69.9 \%)$ in the nCNSL [34] or combined effect of other constituents within it. In a recent work [2] it has been found that Anacardic acid 6-pentadecyl salicylic (6- PSA, 30-150 $\mu \mathrm{M}$ ) from Amphipterygium adstringens induces breaks in DNA (in vitro). Otherwise, Cardanol and Cardol present in crude hexane extracts of propolis exhibited anti-proliferative effects [42].

However, Leite [23] found that the nCNSL at $20 \mathrm{mg} /$ $\mathrm{kg}$ did not induce genotoxic effects in peripheral blood and bone marrow cells in mice; whichever also produced anti-genotoxic effect. The activity attribution may be linked to Anacardic acid [18]. Previous research has reported that the cashew nut exerts antioxidative effect, due to the presence of polyphenols in it [17]. A study with $A$. occidentale pulp proves antioxidant activity in pre-, co- and post-treatment in the presence of hydrogen peroxide $\left(\mathrm{H}_{2} \mathrm{O}_{2}\right)$ in Salmonella typhimurium in Ames 
test. The results were also associated with chemical constituents, such as Anacardic acid [29].

The nCNSL and Cardanol in this study exhibited significant $(p<0.05)$ genotoxic effects than iCNSL compared to the NC group. Thus, there may be other constituents in iCNSL may attribute to this non-genotoxic effect. We can infer that the other phenolic constituents of the CNSLs can also protect cells from damage to the genetic materials (e.g., DNA and RNA). The alkyl resorcinol, for an example, may have anti-genotoxic effect (in vitro) for its ability to interact with biological membranes, giving them an amphipathic character [35]. Other work also associates with the ability to prevent and repair cellular damage [40]. There have been a suggestion for neither genotoxic nor mutagenic effects by a newly synthesized resorcinolic lipid, 3-heptyl-3,4,6trimethoxy-3H-isobenzofuran-1-one in mice [32]. It is noteworthy that only a small quantity of alkyl resorcinol may be considered an antioxidant to prevent oxidation of free fatty acids and phospholipids against peroxidation induced by iron in biological membranes, which can be responsible for its anti-mutagenic activity [9].

Several studies consider that the MN test in rodents erythrocytes of peripheral blood and bone marrow is a primary test for evaluating the genotoxic potential in vivo [10]. In this study, a further analysis was conducted for a better result for mutagenicity investigated in bone marrow cells of mice by means of the MN test to get the clastogenic and/or aneugenic effects of nCNSL, iCNSL and Cardanol. Unlike genotoxicity assessment, the compounds showed no mutagenic effects in comparison to the $\mathrm{NC}$ group.

According to Ferguson (2001) many products can behave as protectors or inducers of damage to genetic material. In this study the genotoxic effect caused by higher concentrations of nCNSL and at all concentrations of Cardanol did not lead to mutagenesis, as it did not induce the formation of $\mathrm{MN}$. Thus, the damage may have been serviced by the cells and thus these compounds would not be able to cause double breaks those are difficult to repair easily. The protective effects could be attributed primarily by scavenging of free radicals by nCNSL, iCNSL and Cardanol [24]. The cashew liquids in this study are a source of phenolic lipids [44] that could enhance the protective activity of the DNA against the action of mutagens. Our findings suggest that none of the tested doses of nCNSL, iCNSL and Cardanol produced cytotoxic effects.

According to Lent et al. [26], nitrotriazolone (3-nitro1,2,4-triazol-5-one) may produce genotoxicity to male rats by inhibiting steroidogenesis and/or direct testicular toxicity. Otherwise, cerium oxide nanoparticles induced genotoxicity in female rats by significant DNA damage and $\mathrm{MN}$ formation as well as total cytogenetic changes in bone marrow cells [22]. In our study female mice were found to be more susceptible to genotoxic damage which may link to the latter case.

\section{Conclusion}

In conclusion, the iCNSL exerted a non-genotoxic effect in mouse bone marrow. However, the nCNSL induced genotoxic damage by the two largest doses in female mice, while the Cardanol produced genotoxicity at all doses. However, non-mutagenic activity by the CNSLs and Cardanols may link to DNA repair. Finally, non-cytotoxic and non-mutagenic activities of the test samples may be a good indication of pharmaceutical consumption.

\section{Acknowledgements \\ The authors thank to the National Council of Technological and Scientific Development (CNPq/Brazil) and the Genetic and Toxicological Research Laboratory, UFPI, Brazil.}

\section{Authors' contributions}

AdeSL, MTI, MFCJP, ALGJ \& GLdaSO performed the laboratory studies and collected data. AMdasGLC performed the statistical analysis, wrote the manuscript. AAdeCMC \& JADL supervised the study and wrote the manuscript. All authors read and approved the final manuscript.

\section{Funding}

This study is approved and performed in UFPI/Brazil and funded by CNPq/ Brazil.

\section{Availability of data and materials \\ Not applicable.}

\section{Ethics approval and consent to participate}

This study (Protocol number: 0440051000-07) was approved by the Research Ethics Committee the National Council of Scientific and Technological Development (CNPq), CAAE, Brazil.

Consent for publication

The authors declare their consent for publication.

\section{Competing interests}

The authors declare that they have no competing interests.

\section{Author details}

${ }^{1}$ Northeast Biotechnology Network (RENORBIO), Postgraduate Program in Pharmaceutical Sciences, Federal University of Piauí, Teresina, PI 64009-550, Brazil. '2Department of Pharmacy, Life Science Faculty, Bangabandhu Sheikh Mujibur Rahman Science and Technology University, Gopalganj, Dhaka 8100, Bangladesh. ${ }^{3}$ Chemistry Department, CCN, Federal University of Piauí, Teresina, PI 64009-550, Brazil. ${ }^{4}$ Postgraduate Program in Pharmaceutical Sciences, Federal University of Piauí, Teresina, PI 64009-550, Brazil.

Received: 28 July 2019 Accepted: 10 October 2019

Published online: 15 November 2019

\section{References}

1. Akaneme Fl, Amaefule CC. Evaluation of the cytotoxicity and genotoxicity of aqueous leaf extracts of Azadirachta indica a. Juss using the Allium test. J Med Plant Res. 2012:6:3898-907.

2. Alam-Escamilla D, Estrada-Muñiz E, Solís-Villegas E, Elizondo G, Vega L. Genotoxic and cytostatic effects of 6-pentadecyl salicylic Anacardic acid in transformed cell lines and peripheral blood mononuclear cells. Mutat Res/ Genet Toxicol Environ Mutagen. 2015;777:43-53.

3. Andrade TDJADS, Araújo BQ, AMDGL C, da Silva J, Saffi J, Richter MF, ABF F. Antioxidant properties and chemical composition of technical cashew nut Shell liquid (tCNSL). Food Chem. 2011;126:1044-8. 
4. Behravan E, Heidari MR, Heidari M, Fatemi G, Etemad L, Taghipour G, Abbasifard M. Comparison of gastric ulcerogenicity of percolated extract of Anacardium occidentale (cashew nut) with indomethacin in rats. Pak J Pharm Sci. 2012;25:111-5.

5. Cheriyan S, Abraham ET. Enzymatic bioremediation of cashew nut shell liquid contamination. J. Hazard Mater. 2010;176:1097-100.

6. Das P, Sreelatha T, Ganesh A. Bio oil from pyrolysis of cashew nut shellcharacterisation and related properties. Biomass Bioenergy. 2004;27:265-75.

7. De Lima SG, Feitosa CM, Citó AM, Moita Neto JM, Lopes JA, Leite AS, Brito MC, Dantas SM, Cavalcante AA. Effects of immature cashew nut-shell liquid (Anacardium occidentale) against oxidative damage in Saccharomyces cerevisiae and inhibition of acetylcholinesterase activity. Genet Mol Res. 2008;7(3):806-18.

8. de Souza MQ, Teotônio IMSN, de Almeida FC, Heyn GS, Alves PS, Romeiro LAS, Pratesi R, de Medeiros Nóbrega YK, Pratesi CB. Molecular evaluation of anti-inflammatory activity of phenolic lipid extracted from cashew nut shell liquid (CNSL). BMC Complement Altern Med. 2018; 18(1):181.

9. Deszcz L, Kozubek A. Higher Cardol homologs (5-alkylresorcinols) in rye seedlings. Biochim Biophys Acta (BBA) - Molecul Cell Biol Lipids. 2000; 1483:241-50.

10. Eastmond DA, Hartwig A, Anderson D, Anwar WA, Cimino MC, Dobrev I, Douglas GR, Nohmi T, Phillips DH, Vickers C. Mutagenicity testing for chemical risk assessment: update of the WHO/IPCS harmonized scheme Mutagen. 2009;24:341-9.

11. Edziri H, Mastouri M, Aouni M, Anthonissen R, Verschaeve L. Investigation on the genotoxicity of extracts from Cleome amblyocarpa Barr. And Murb, an important Tunisian medicinal plant. South Afric J Bot. 2013;84:102-3.

12. Engels $C$, Gräter $D$, Esquivel $P$, Jiménez VM, Gänzle MG, Schieber A. Characterization of phenolic compounds in jocote (Spondias purpurea L.) peels by ultra high-performance liquid chromatography/electrospray ionization mass spectrometry. Food Res Int. 2012;46:557-62.

13. Farias DF, Cavalheiro MG, Viana SM, De Lima GP, da Rocha-Bezerra LC, Ricardo NM, Carvalho AF. Insecticidal action of sodium anacardate from Brazilian cashew nut shell liquid against Aedes aegypti. J Am Mosq Control Assoc. 2009;25(3):386-9.

14. Gomes Júnior AL, Tchekalarova JD, Machado KDC, Moura AKS, Paz MFCJ, da Mata AMOF, Nogueira TR, Islam MT, Rios MAS, Graças Lopes Citó AMD, Uddin SJ, Shilpi JA, Das AK, Lopes LDS, Melo-Cavalcante AAC. Anxiolytic effect of anacardic acids from cashew (Anacardium occidentale) nut shell in mice. IUBMB Life. 2018;70(5):420-31.

15. Holland N, Bolognesi C, Kirsch-Volders M, Bonassi S, Zeiger E, Knasmueller S, Fenech M. The micronucleus assay in human buccal cells as a tool for biomonitoring DNA damage: the HUMN project perspective on current status and knowledge gaps. Mutat Res/Rev Mutat Res. 2008;659:93-108.

16. Isidorov VA, Isidorova AG, Sczczepaniak L, Czyżewska U. Gas chromatographic-mass spectrometric investigation of the chemical composition of beebread. Food Chem. 2009:115:1056-63.

17. Kamath V, Rajini PS. The efficacy of cashew nut (Anacardium occidentale L.) skin extract as a free radical scavenger. Food Chem. 2007:103:428-33.

18. Kannan VR, Sumathi C, Balasubramanian V, Ramesh N. Elementary chemical profiling and antifungal properties of cashew (Anacardium occidentale L.) nuts. Bot Res Int. 2009;2:253-7.

19. Kongkachuichai $R$, Charoensiri $R$, Yakoh K, Kringkasemsee A, Insung P. Nutrients value and antioxidant content of indigenous vegetables from southern Thailand. Food Chem. 2015;173:838-46.

20. Kubo I, Masuoka N, Ha TJ, Tsujimoto K. Antioxidant activity of Anacardic acid. Food Chem. 2006;99:555-62

21. Kumar PP, Paramashivappa R, Vithayathil PJ, Rao PVS, Rao AS. Process for isolation of Cardanol from technical cashew (Anacardium occidentale L.) nut Shell liquid. J Agric Food Chem. 2012;50:4705-8.

22. Kumari M, Kumari SI, Kamal SSK, Grover P. Genotoxicity assessment of cerium oxide nanoparticles in female Wistar rats after acute oral exposure. Mutat Res/Genetic Toxicol Environ Mutagen. 2014;775-776:7-19.

23. Leite AS. 2009. Study of the genotoxic and mutagenic activities of cashew nut liquid (Anacardium occidentale) for biotechnological applications. 2009. 100f. Dissertation. (master of genetics and applied toxicology). Lutheran University of Brazil., Canoas, 2009.

24. Leite AS, Gomes DCV, Oliveira GLS, Paz MFC, Carvalho RM, Mata AMOF, Alencar MVOB, Júnior ALG, Sousa JMC, Islam MT, AMdGL C, AAC M-C, JAD L.
Net effects of cashew nuts in Saccharomyces cerevisiae front to damage induced by hydrogen peroxide. Int Arch Med. 2016;9:1-13.

25. Leite Ade S, Dantas AF, Oliveira GL, Gomes Júnior AL, de Lima SG, Citó AM, de Freitas RM, Melo-Cavalcante AA, Dantas Lopes JA Evaluation of toxic, cytotoxic, mutagenic, and antimutagenic activities of natural and technical cashew nut shell liquids using the Allium cepa and Artemia salina bioassays. Biomed Res Int. 2015;2015:626835.

26. Lent EM, Crouse LCB, Wallace SM, Carroll EE. Peri-pubertal administration of 3-nitro-1,2,4-triazol-5-one (NTO) affects reproductive organ development in male but not female Sprague Dawley rats. Reprod Toxicol. 2015;57:1-9.

27. M Ashraf S, Rathinasamy K. Antibacterial and anticancer activity of the purified cashew nut shell liquid: implications in cancer chemotherapy and wound healing. Nat Prod Res. 2018;32(23):2856-60.

28. Madureira AM, Ramalhete C, Mulhovo S, Duarte A, Ferreira MJ-U. Antibacterial activity of some African medicinal plants used traditionally against infectious diseases. Pharm Biol. 2012;50:481-9.

29. Melo-Cavalcante AAC, Dantas SMMM, Leite AS, Matos LA, Sousa JMC, Picada JN, Silva J. In vivo antigenotoxic and anticlastogenic effects of fresh and processed cashew (Anacardium occidentale) apple juices. J Med Food. 2011;14:792-8

30. Miller B, Pötter-Locher F, Seelbach A, Stopper H, Utesch D, Madle S. Evaluation of the in vitro micronucleus test as an alternative to the in vitro chromosomal aberration assay: position of the GUM working group on the in vitro micronucleus test. Mutat Res/Rev Mutat Res. 1998:410:81-116.

31. Morais TC, Pinto NB, Carvalho KMMB, Rios JB, Ricardo NMPS, Trevisan MTS, Rao VS, Santos FA. Protective effect of Anacardic acid $s$ from cashew (Anacardium occidentale) on ethanol-induced gastric damage in mice. Chem Biol Interact. 2010;183:264-9.

32. Navarro SD, Beatriz A, Meza A, Pesarini JR, Gomes RDS, Karaziack CB, Cunha-Laura AL, Monreal AC, Romão W, Lacerda Júnior $V$, Mauro Mde O, Oliveira RJ. A new synthetic resorcinolic lipid 3-Heptyl-3,4,6trimethoxy-3H-isobenzofuran-1-one: evaluation of toxicology and ability to potentiate the mutagenic and apoptotic effects of cyclophosphamide. Eur J Med Chem. 2014;75:132-42.

33. Ogunsina BS, Bamgboye Al. Pre-shelling parameters and conditions that influence the whole kernel out-turn of steam-boiled cashew nuts. J Saudi Soc Agric Sci. 2014;13:29-34.

34. Oliveira MSC, Morais SMD, Magalhães DV, Batista WP, Vieira IGP, Craveiro AA, de Manezes JE, Carvalho AF, de Lima GP. Antioxidant, larvicidal and antiacetylcholinesterase activities of cashew nut shell liquid constituents. Acta Trop. 2011;117:165-70.

35. Parikka K, Rowland IR, Welch RW, Wähälä K. In Vitro antioxidant activity and Antigenotoxicity of 5-n-Alkylresorcinols. J Agric Food Chem. 2006;54:1646-50.

36. Patel RN, Bandyopadhyay S, Ganesh A. Extraction of Cardanol and phenol from bio-oils obtained through vacuum pyrolysis of biomass using supercritical fluid extraction. Energy. 2011;36:1535-42.

37. Recio L, Hobbs C, Caspary W, Witt KL. Dose-response assessment of four genotoxic chemicals in a combined mouse and rat micronucleus and comet assay protocol. J Toxicol Sci. 2010;35:149.

38. Serpeloni JM, Reis MB, Rodrigues J, Santos LC, Vilegas W, Varanda EA, Dokkedal AL, Cólus IM. In vivo assessment of DNA damage and protective effects of extracts from Miconia species using the comet assay and micronucleus test. Mutagen. 2008;23:501-7.

39. Song NR, Yang H, Park J, Kwon JY, Kang NJ, Heo YS, Lee KW, Lee HJ. Cyanidin suppresses neoplastic cell transformation by directly targeting phosphatidylinositol 3-kinase. Food Chem. 2012;133:658-64.

40. Stepanenko IY, Strakhovskaya MG, Belenikina NS, Nikolaev YA, Mulyukin AL, Kozlova AN, Revina AA, El'-Registan GI. Protection of Saccharomyces cerevisiae against oxidative and radiation-caused damage by Alkylhydroxybenzenes. Microbiol. 2004;73:163-9.

41. Tedong L, Madiraju P, Martineau LC, Vallerand D, Arnason JT, Desire DD, Lavoie L, Kamtchouing P, Haddad PS. Hydro-ethanolic extract of cashew tree (Anacardium occidentale) nut and its principal compound, Anacardic acid, stimulate glucose uptake in C2C12 muscle cells. Mol Nutr Food Res. 2010;54:1753-62.

42. Teerasripreecha D, Phuwapraisirisan P, Puthong S, Kimura K, Okuyama M, Mori H, Kimura A, Chanchao C. In vitro antiproliferative/cytotoxic activity on cancer cell lines of a Cardanol and a Cardol enriched from Thai Apis mellifera propolis. BMC Complement Altern Med. 2012;12:27. 
43. Tice RR, Agurell E, Anderson D, Burlinson B, Hartmann A, Kobayashi H, Miyamae Y, Rojas E, Ryu JC, Sasaki YE. Single cell gel/comet assay: guidelines for in vitro and in vivo genetic toxicology testing. Environ Mol Mutagen. 2000;35:206-21.

44. Trevisan M, Pfundstein B, Haubner R, Wurtele G, Spiegelhalder B, Bartsch H, Owen RW. Characterization of alkyl phenols in cashew (Anacardium occidentale) products and assay of their antioxidant capacity. Food Chem Toxicol. 2006:44:188-97.

\section{Publisher's Note}

Springer Nature remains neutral with regard to jurisdictional claims in published maps and institutional affiliations.

\section{Submit your manuscript to a SpringerOpen ${ }^{\circ}$ journal and benefit from:}

- Convenient online submission

- Rigorous peer review

- Open access: articles freely available online

- High visibility within the field

- Retaining the copyright to your article

Submit your next manuscript at $\boldsymbol{\nabla}$ springeropen.com 